\title{
Correlations of Crop Load and Return Bloom with Root and Shoot Concentrations of Potassium, Nitrogen, and Nonstructural Carbohydrates in Pecan
}

\author{
Michael W. Smith ${ }^{1,4}$, Charles T. Rohla ${ }^{2}$, and Niels O. Maness ${ }^{3}$ \\ Department of Horticulture \& Landscape Architecture, 360 Agricultural Hall, \\ Oklahoma State University, Stillwater, OK 74078
}

\begin{abstract}
AdDITIONAL INDEX wORDs. alternate bearing, irregular bearing, Carya illinoinensis, fruit, flower, flowering
Abstract. The current theory of pecan [Carya illinoinensis (Wangenh.) C. Koch] alternate bearing is the "growth regulator-carbohydrate theory" in which flowering is first controlled by growth regulators produced by fruit and leaves, and then by the size of the carbohydrate pool near budbreak. Lack of nitrogen $(N)$ reserves has also been proposed to be limiting after large crops, thus reducing return bloom. Annual production was determined for 12 individual trees for 3 years. Return bloom was monitored on four previous-season shoot types: 1) vegetative shoots, 2) bearing terminal shoots without a second growth flush, 3) bearing lateral shoots without a second growth flush, and 4) bearing shoots that were primarily in the terminal position with a second growth flush. Nonstructural carbohydrates, organically bound $\mathrm{N}$, and potassium $(\mathrm{K})$ concentrations were determined in roots and shoots. Regression analysis was used to determine the effect of yield on subsequent nonstructural carbohydrates, $\mathrm{N}$, and $\mathrm{K}$ in the roots and shoots, and their postyield concentrations on subsequent flowering. Alternate bearing was evident because there were reductions of $18 \%, 16 \%$, and $18 \%$ in the percentage of current season shoots flowering for every $10 \mathrm{~kg} /$ tree production increase in the previous season's yield in 2002, 2003, and 2004 respectively. Flower production in 2002 decreased by 2.6 flowers/ 1-year-old branch and 1.6 flowers/1-year-old branch in 2003 for each $10 \mathrm{~kg} /$ tree increase in production. The third year of the study, neither previous season shoot type nor yield affected subsequent flower production. The previous year's shoot type did not affect the percentage of current season shoots flowering; however, the previous year's shoots that had a second growth flush produced more flowers the following year than the other shoot types. Results suggested that crop load was not related to nonstructural carbohydrates, $\mathrm{N}$, or $\mathrm{K}$ in the roots and shoots during January in these wellmanaged trees. Stored nonstructural carbohydrates, $\mathbf{N}$, and $\mathrm{K}$ were also not related to return bloom. These data suggest that the current "growth regulator-carbohydrate theory" may not be valid in these well-managed trees. Nonstructural carbohydrates, $K$, and organically bound $N$ do not appear to be critical factors regulating flowering.
\end{abstract}

Alternate or irregular bearing is the most significant horticultural problem in pecan production. Alternate bearing is typically synchronized over regions by biotic or abiotic stresses and results in high-amplitude cycling (Gemoets et al., 1976; Wood, 1993). Irregular and often unpredictable production negatively impacts all economic aspects of pecan production and marketing.

The currently supported theory for pecan alternate bearing is the "growth regulator-carbohydrate theory." This theory evolved over years of research and contributions by several scientists. The origins of the theory began when Smith and Waugh (1938) reported that stored carbohydrate levels markedly affected subsequent flowering. The role of carbohydrates in flowering has been supported by several studies (Malstrom, 1974; Sparks and Brack, 1972; Wood, 1989, 1991; Worley,

Received for publication 15 June 2006. Accepted for publication 28 Sept. 2006. Funding for this study was provided by the Oklahoma Agricultural Expt. Sta., USDA Crop Germplasm Committee, and the Oklahoma Pecan Growers' Association.

Approved for publication by the Oklahoma Agricultural Expt. Sta.

${ }^{1}$ Regents Professor.

${ }^{2}$ Former graduate student. Current address: Samuel Roberts Noble Foundation, Ardmore, OK 73402.

${ }^{3}$ Professor.

${ }^{4}$ Corresponding author: E-mail: mike.smith@okstate.edu 1979a, b). Barnett and Mielke (1981) suggested that phytohormones may be involved in regulation of pecan alternate bearing. The involvement of phytohormones or growth regulators has been supported by several studies (Amling and Amling, 1983; Smith et al., 1986; Wood, 2003; Wood and McMeans, 1981).

There are inconsistencies related to the involvement of stored carbohydrates regulating return bloom. For instance, Wood et al. (2003) reported that there was no association between alternate-bearing intensity and fruit ripening date or nut volume. In addition, as the postripening foliation period increased, alternate bearing increased. Weak or nonsignificant relationships have been reported between cluster size and return bloom (Rohla et al., 2005), suggesting little role for carbohydrates in regulating return bloom. Another study found stored carbohydrates in bearing shoots was greater than in vegetative shoots, although return bloom of bearing shoots was depressed relative to vegetative shoots (Smith et al., 1986). These studies bring into question the role of nonstructural carbohydrates in regulating alternate bearing.

Nitrogen applications have generally increased pecan yield (Brooks and Livingston, 1962; Hunter, 1964; Hunter and Hammar, 1947, 1961; Skinner, 1922; Smith and Hamilton, 1937; Smith et al., 1985; Sparks, 1968; Taylor, 1930; Worley, 1974, 1990). Traditionally, nitrogen (N) has been applied as a 
single application shortly before budbreak or split between budbreak followed by a May or June application. However, scientists suggested that a critical $\mathrm{N}$ shortage develops in the fall during years with large crops, "on-years," that contributes to alternate bearing (Goff et al., 2001; Kraimer et al., 2004; Wood, 2001b).

Potassium $(\mathrm{K})$ could be limiting during on-years because developing fruit may deplete leaf K (Diver and Smith, 1984; Krezdorn, 1955; Sparks, 1977) that simultaneously accumulates in shuck and kernel tissue during fruit ripening (Diver and Smith, 1984). Additionally, leaf K concentration and kernel oil content are closely associated (Hunter and Hammar, 1956). Transport of sugars and amino compounds in the phloem is accomplished by osmotically generated hydrostatic pressure differences between the source and sink (Lalonde et al., 2003). Adequate $\mathrm{K}$ favors phloem loading by improving adenosine triphosphate synthesis, a high energy source required for phloem loading (Haeder, 1977; Mengel, 1980). Studies have provided evidence that $\mathrm{K}$ increases flux rates without diluting phloem sap content of organic solutes (Mengel, 1980; Mengel and Haeder, 1977), thus transport rates are substantially faster when adequate $\mathrm{K}$ is available. Vreugdenhil (1985) demonstrated that the $\mathrm{K}$ gradient in the phloem coincided with the direction of flow. Thus, $\mathrm{K}$ availability affects both phloem loading and transport (Haeder, 1977; Vreugdenhil, 1985), and consequently fruit development, yield, and potentially alternate bearing.

The objective of this study was to determine the relationship of nonstructural carbohydrates, $\mathrm{K}$, and organically bound $\mathrm{N}$ during January in selected tissues with the previous crop yield and subsequent season flowering. Vigorous, exceptionally well-managed 'Pawnee' trees that were alternate bearing were chosen for the study to eliminate any casual relationships between nonstructural carbohydrates, K, or organically bound $\mathrm{N}$ with crop load or flowering that might be apparent in less vigorous trees. For instance, a low-vigor tree with a large crop is likely to have few stored carbohydrates. If a small crop follows, it is unclear whether the lack of return bloom was associated with depressed nonstructural carbohydrates or was suppressed for other causes and the relationship with stored carbohydrates was casual. This study determined the relationships of 1) crop load with return bloom and the concentrations of nonstructural carbohydrates, $\mathrm{K}$, and organically bound $\mathrm{N}$; and 2) stored carbohydrates, $\mathrm{K}$, and organically bound $\mathrm{N}$ with return bloom. Return bloom was characterized for four shoot types.

\section{Materials and Methods}

Twelve 13-year-old 'Pawnee' trees growing in a Teller sandy loam (fine-loamy, mixed, active, thermic, Udic Argiustolls) in a commercially managed orchard near Charlie, Texas, were selected based on uniformity of size, vigor, initial crop load ( $85 \%$ to $90 \%$ bearing shoots), and location within the orchard. Trees were spaced $12.2 \times 12.2 \mathrm{~m}$ apart with $19.7 \pm$ 2.1-cm-diameter trunks measured $1.4 \mathrm{~m}$ above the ground at the beginning of this study.

The entire orchard floor was maintained vegetation free throughout the growing season with glyphosate. Trees received supplemental irrigation from microsprinklers during April through October. Urea was surface applied in 2001 in a split application at the rate of $112 \mathrm{~kg} \cdot \mathrm{ha}^{-1} \mathrm{~N}$ in March, $112 \mathrm{~kg} \cdot \mathrm{ha}^{-1} \mathrm{~N}$ in June, and $84 \mathrm{~kg} \cdot \mathrm{ha}^{-1} \mathrm{~N}$ in October. Water samples taken during 2001 revealed that the groundwater used for irrigation was contaminated with $34 \mu \mathrm{g} \cdot \mathrm{L}^{-1} \mathrm{NO}_{3}-\mathrm{N}$. In subsequent years trees received only the $\mathrm{N}$ from irrigation water. This resulted in the application of $141 \mathrm{~kg} \cdot \mathrm{ha}^{-1} \mathrm{~N}$ in 2002 and $191 \mathrm{~kg} \cdot \mathrm{ha}^{-1} \mathrm{~N}$ in 2003. Zinc was applied five times between budbreak and July each year at $2.4 \mathrm{~kg} \cdot \mathrm{ha}^{-1} \mathrm{Zn}$ from $36 \% \mathrm{ZnSO}_{4}$. Pest management followed extension recommendations for a commercial orchard (von Broembsen and Mulder, 2005).

Entire trees were hand thinned by removing individual fruit within clusters when the ovule was about one half expanded in early August, and some trees were not thinned. This produced a wide range in crop loads among trees. Return bloom was monitored on four previous-year shoot types: 1) vegetative shoots, 2) bearing shoots without a second growth flush in the terminal position on 1-year-old branches, 3) bearing shoots without a second growth flush in the lateral position on 1-yearold branches, and 4) bearing shoots that were primarily in the terminal position with a second growth flush. Thirty shoots per tree of each type were tagged at shuck split to monitor return bloom. Shoots of each type were selected at random throughout the canopy. The following spring the number of pistillate flowers produced/1-year-old branch and the percentage of current season's shoots flowering on each type of 1-year-old tagged branch were determined. Total yield per tree was measured annually.

In January, while trees were dormant, root and shoot samples were collected annually. Root samples were collected from a 1-m wide, 2-m long hole by about $0.5 \mathrm{~m}$ deep that was 2 to $3 \mathrm{~m}$ from the trunk. A new location was chosen annually to sample roots. Roots were separated into samples of less than $1 \mathrm{~cm}$ and $\geq 1 \mathrm{~cm}$ in diameter, and then washed in tap water to remove adhering soil. Previous season's vegetative shoots and bearing terminal and lateral shoots without a second growth flush were collected from the canopy periphery. Roots and shoots were stored at $0{ }^{\circ} \mathrm{C}$ until they were freeze-dried to a constant weight. Samples were ground in a Wiley mill to pass through a 20 -mesh screen, and then stored in an airtight glass jar at $0{ }^{\circ} \mathrm{C}$ until analyzed. Organically bound $\mathrm{N}$ was analyzed by the macro-Kjeldahl method (Horowitz, 1980), and K was analyzed using atomic absorption spectroscopy. Nonstructural carbohydrates (starch, reducing and nonreducing sugars) were determined using Nelson's modification of Somogyi's method (Hodge and Hofreiter, 1962) that has been used to analyze nonstructural carbohydrates in pecan tissue (Smith et al., 1986; Wood, 1984, 1989).

Twelve trees were included in the study. Return bloom was monitored on 30 shoots of each type per tree (i.e., 360 shoots of each of four types). The study was repeated for 3 years. Regressions using least squares analysis techniques tested for significant main effects and interactions of shoot type and crop load affecting the percentage of current season shoots flowering and flowers/1-year-old branch. Pearson's coefficients of correlation were calculated for crop load and return bloom with nonstructural carbohydrates, $\mathrm{K}$, and organically bound $\mathrm{N}$.

\section{Results and Discussion}

The percentage of current season shoots flowering was negatively related to the previous season's yield (Fig. 1). There were reductions of $18 \%, 16 \%$, and $18 \%$ in the percentage of current season shoots flowering for every $10 \mathrm{~kg} /$ tree increase in previous season's yield in 2002, 2003, and 2004 respectively. Current season shoots flowering in 2002 and 2003 were unaffected by previous season shoot type. There was no 


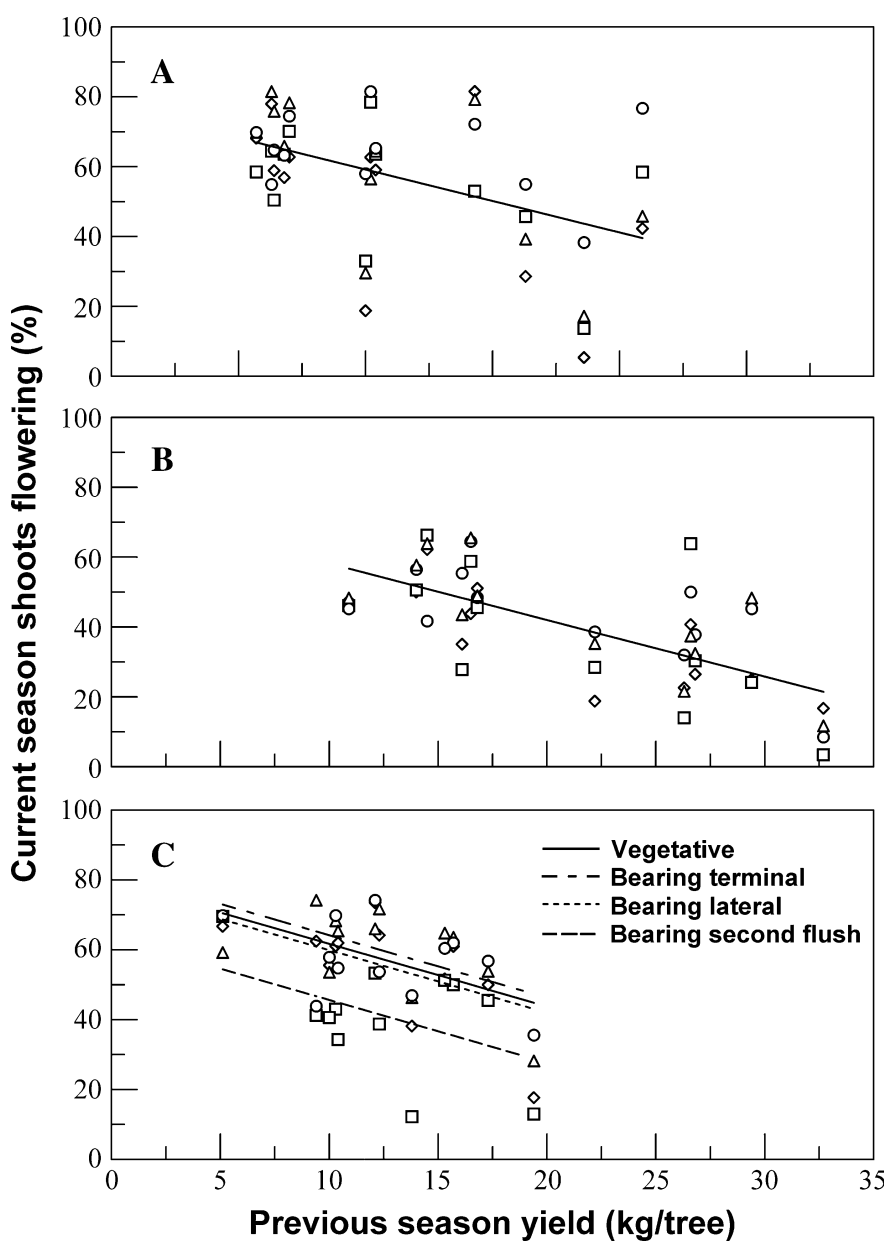

Fig. 1. Pecan tree yield and shoot type related to the subsequent year's percentage of current season shoots producing pistillate flowers. The shoot types were vegetative [VEG (circle)], bearing terminal shoots [BTS (triangle)], bearing lateral shoots [BLS (diamond)], and bearing shoots with a second growth flush [BSF (square)]. Shoot types for 2001 and 2002 yield were not significantly different. (A) 2001 yield with 2002 flowering shoots pooled over previous season shoot types. $\mathrm{Y}=77.3-1.79 \mathrm{X}, R^{2}=0.23, P>\mathrm{F}=0.0006$. (B) 2002 yield with 2003 flowering shoots pooled over previous season shoot types. $\mathrm{Y}=74.4-1.61 \mathrm{X}, R^{2}=0.47, P>\mathrm{F}=0.0001$. (C) 2003 yield with 2004 flowering shoots. VEG: $\mathrm{Y}=79.6-1.79 X$; BTS: $\mathrm{Y}=82.1-1.79 \mathrm{X}$; BLS: $\mathrm{Y}=$ $77.8-1.79 \mathrm{X}$; BSF: $\mathrm{Y}=63.5-1.79 \mathrm{X} ; R^{2}=0.45, P>\mathrm{F}=0.0004$; where $\mathrm{Y}$ is the percent current season shoots flowering and $\mathrm{X}$ is the previous season yield/tree in kilograms.

interaction between shoot type and yield (no difference in slopes among shoot types) affecting the percentage of current season shoots flowering during any year; however, in 2004 the main effect of shoot type was significant (different intercepts).

The number of flowers/1-year-old branch produced the following year was affected by shoot type and negatively related to yield during 2 of 3 years (Fig. 2). However, there were no interactions between previous year's shoot type and yield affecting flowers/branch. In 2002, shoots that had a second growth flush produced substantially more flowers than the other shoot types. Differences in flower production among the other three shoots were small. Flower production in 2002 decreased by 2.6 flowers/1-year-old branch for each $10 \mathrm{~kg} /$ tree of production. In 2003, shoots that had a second growth flush produced the most flowers, and bearing lateral shoots produced the least. Flower production was reduced by 1.6 flowers/

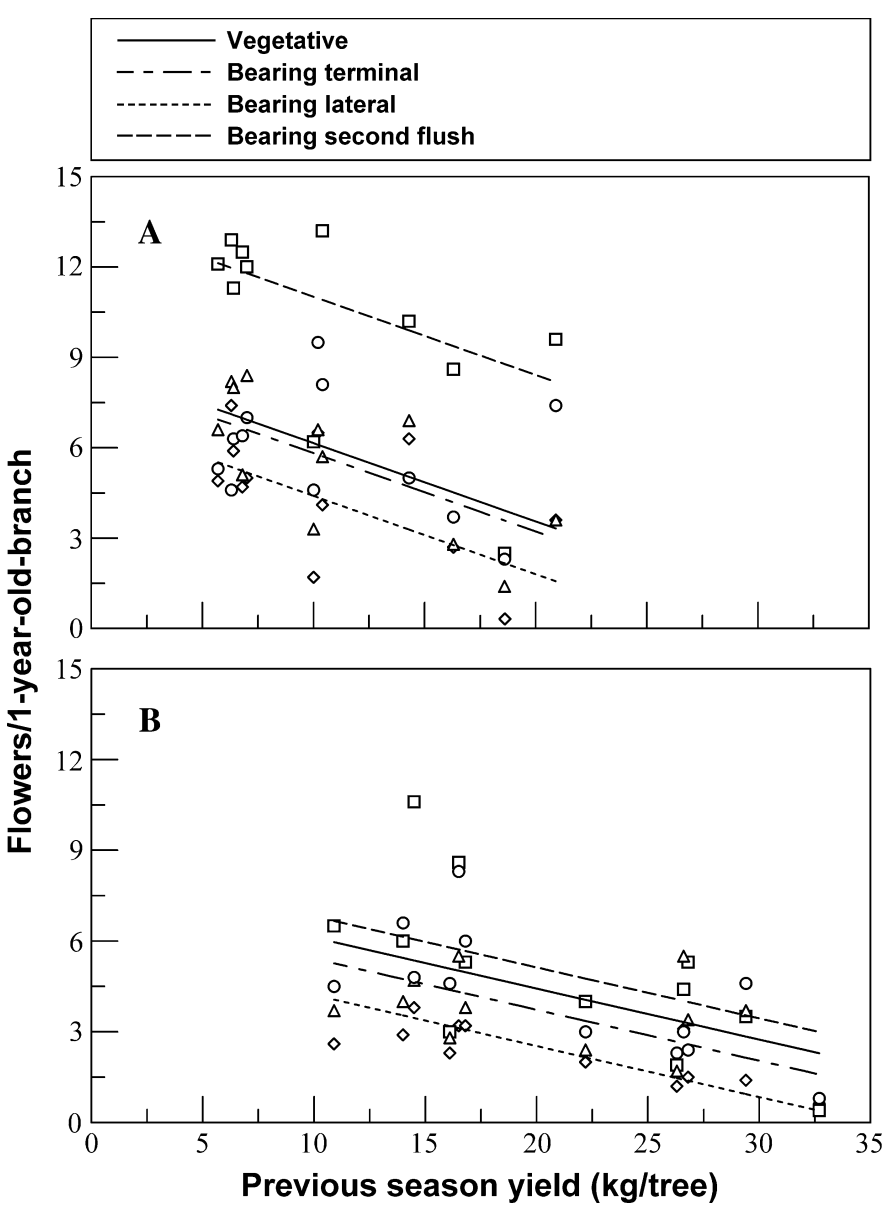

Fig. 2. Pecan tree yield and shoot type related to the number of flowers per 1-year-old branch the following year. The shoot types were vegetative [VEG (circle)], bearing terminal shoots [BTS (triangle)], bearing lateral shoots [BLS (diamond)], and bearing shoots with a second growth flush [BSF (square)]. (A) 2001 yield with 2002 flowers. VEG: $\mathrm{Y}=8.7-0.26 \mathrm{X}$; BTS: $\mathrm{Y}=8.4-$ 0.26X; BLS: $\mathrm{Y}=7.3-0.26 \mathrm{X}$; BSF: $\mathrm{Y}=13.6-0.26 \mathrm{X}, R^{2}=0.61, P>$ $\mathrm{F}=0.0003$. (B) 2002 yield with 2003 flowers. VEG: $\mathrm{Y}=7.8-0.17 \mathrm{X}$; BTS: $\mathrm{Y}=7.1-0.17 \mathrm{X}$; BLS: $\mathrm{Y}=5.9-0.17 \mathrm{X}$; BSF: $\mathrm{Y}=8.2-0.17 \mathrm{X}, R^{2}=0.51, P>$ $\mathrm{F}=0.0001$; where $\mathrm{Y}$ is the number of flowers/branch and $\mathrm{X}$ is the previous season yield/tree in kilograms.

1-year-old branch for each $10 \mathrm{~kg} /$ tree of production. The third year of the study, neither previous season shoot type nor yield affected subsequent flower production (data not shown).

There was only one significant correlation between yield and nonstructural carbohydrate concentrations stored in the roots the following January (Table 1). Production intensity also had little influence on nonstructural carbohydrates in the shoots. Others have reported little effect of yield on shoot carbohydrates or that bearing shoots had more nonstructural carbohydrates than vegetative shoots (Smith et al., 1986; Wood, 1989; Wood and McMeans, 1981). There was a positive correlation between starch concentration and yield for bearing terminal shoots in 2003 and vegetative shoots in 2004. However, in most instances, yield did not affect nonstructural carbohydrates. This suggests that carbohydrates were not limiting because kernel yield was good for 'Pawnee', averaging $57.6 \%, 57.2 \%$, and $55.5 \%$ for 2002,2003 , and 2004 respectively, and nonstructural carbohydrates in the roots and shoots during January were rarely related to previous season's yield (Table 1). 
Table 1. Coefficients of correlation between individual tree yield with nonstructural carbohydrate concentration the following January in small and large roots, vegetative shoots, bearing terminal shoots, or bearing lateral shoots of pecan.

\begin{tabular}{lccc}
\hline Nonstructural & \multicolumn{3}{c}{ Coefficient of correlation } \\
\cline { 2 - 4 } carbohydrate & 2002 & 2003 & 2004 \\
\hline \multirow{4}{*}{ Roots $<1$ cm diameter } \\
Starch & -0.05 & $-0.68^{*}$ & -0.21 \\
Nonreducing sugar & 0.12 & 0.08 & -0.10 \\
Reducing sugar & 0.52 & -0.55 & -0.07 \\
Total & 0.29 & -0.24 & -0.15 \\
& Roots $\geq$ cm diameter & \\
Starch & 0.13 & -0.18 & -0.19 \\
Nonreducing sugar & 0.06 & 0.06 & 0.07 \\
Reducing sugar & -0.10 & 0.02 & 0.29 \\
Total & 0.07 & -0.04 & 0.17 \\
& Vegetative shoot & \\
Starch & 0.33 & 0.49 & $0.78^{* *}$ \\
Nonreducing sugar & -0.09 & 0.16 & -0.43 \\
Reducing sugar & -0.31 & -0.36 & -0.03 \\
Total & -0.21 & 0.20 & -0.39 \\
Starch & Bearing terminal shoot & \\
Nonreducing sugar & 0.30 & $0.80^{* *}$ & -0.10 \\
Reducing sugar & 0.25 & -0.14 & -0.43 \\
Total & 0.07 & 0.39 & 0.12 \\
& 0.25 & 0.20 & -0.41 \\
Starch & Bearing lateral shoot & \\
Nonreducing sugar & - & - & -0.51 \\
Reducing sugar & - & - & -0.33 \\
Total & - & - & -0.44 \\
****Significantly correlated at 5\% or 1\%, respectively &
\end{tabular}

The percentage of current season shoots flowering was rarely correlated with the concentration of nonstructural carbohydrates in the roots during January (Table 2). In those few instances when the correlation was significant, the relationship was negative six of seven times. Nonstructural carbohydrates in the roots were also rarely correlated with the total number of flowers that were produced from 1-year-old branches (Table 3). Worley (1979a) reported a strong linear correlation between Nov. nonstructural carbohydrates and subsequent yield of 9-year-old 'Farley' trees. Smith and Waugh (1938) stated that starch was the most variable constituent of the nonstructural carbohydrates and appeared to have a marked influence on fruiting of 45-year-old seedling pecan trees. Malstrom (1974) reported a positive relationship between January root starch concentration and subsequent yield of 60-year-old 'Moneymaker' pecan trees. Wood (1989) reported a positive correlation between January root starch concentration and subsequent yield of $\approx 80$-year-old 'Stuart' and 'Schley' trees. Worley's (1979a) 'Farley' trees averaged $\approx 21 \%$ total nonstructural carbohydrates and $13 \%$ starch in roots less than $1.3 \mathrm{~cm}$ in diameter during January. Total nonstructural carbohydrates during January in Smith and Waugh's (1938) seedling trees averaged $\approx 11.5 \%$ and $7 \%$ starch (converted to a dry weight basis) in $0.15-\mathrm{cm}$ to $1.3-\mathrm{cm}$-diameter roots. Nonstructural carbohydrates during Jan. in $0.6-\mathrm{cm}$ to 1.9 -cm-diameter roots averaged $\approx 17.6 \%$ and $9.6 \%$ starch in Malstrom's (1974) 'Moneymaker' trees. Wood's (1989) 80-year-old 'Stuart' and 'Schley' trees averaged $5.7 \%$ and $5.1 \%$ respectively in total nonstructural carbohydrates, and $3.7 \%$ and $3.3 \%$ starch in roots up to $4 \mathrm{~cm}$ in diameter during January. Nonstructural carbohydrates in the 'Pawnee' trees in this study ranged from $19 \%$ to $25 \%$ in roots $\geq 1 \mathrm{~cm}$ in diameter and $22 \%$ to $26 \%$ in roots less than $1 \mathrm{~cm}$ in diameter, and starch concentrations were $1 \%$ to $7.7 \%$ and $0.4 \%$ to $2.4 \%$ in large and small roots respectively, depending on the year. Total nonstructural carbohydrates in roots reported here were higher than in previous studies, although starch concentrations were lower. The earlier studies reported correlations between dormant season root starch and subsequent yield, but not for total nonstructural carbohydrates and yield (Malstrom, 1974; Smith and Waugh, 1938; Wood, 1989; Worley 1979a). It seems unreasonable that starch concentrations in the roots predict subsequent yield whereas total nonstructural carbohydrates do not. Starch, nonreducing sugar, and reducing sugar are readily converted from one form to another depending on environmental conditions and tree activity. Root concentration of total nonstructural carbohydrates found in this study was substantially higher than reported in other studies. There was no consistent relationship between any form of nonstructural carbohydrate or total nonstructural carbohydrates with

Table 2. Coefficients of correlation between nonstructural carbohydrate concentrations in small and large pecan roots during January with the percentage of current shoots flowering the following spring that developed from the previous year's shoot types.

\begin{tabular}{|c|c|c|c|c|c|c|c|c|c|c|c|c|}
\hline \multirow{3}{*}{$\begin{array}{l}\text { Nonstructural } \\
\text { carbohydrate }\end{array}$} & \multicolumn{12}{|c|}{ Coefficient of correlation for previous year's shoot type } \\
\hline & \multicolumn{3}{|c|}{ Vegetative shoot } & \multicolumn{3}{|c|}{ Bearing terminal shoot } & \multicolumn{3}{|c|}{ Bearing lateral shoot } & \multicolumn{3}{|c|}{$\begin{array}{l}\text { Bearing with a second } \\
\text { growth flush }\end{array}$} \\
\hline & 2002 & 2003 & 2004 & 2002 & 2003 & 2004 & 2002 & 2003 & 2004 & 2002 & 2003 & 2004 \\
\hline Starch & -0.37 & 0.13 & $0.60 *$ & -0.17 & 0.24 & 0.24 & -0.26 & 0.34 & 0.33 & -0.40 & 0.20 & 0.16 \\
\hline Nonreducing sugar & -0.30 & 0.12 & -0.11 & $-0.62 *$ & 0.07 & 0.08 & $-0.30 * *$ & -0.09 & 0.11 & -0.24 & 0.06 & 0.34 \\
\hline Reducing sugar & -0.24 & 0.24 & 0.44 & $-0.71 * *$ & 0.02 & 0.08 & $-0.64 *$ & 0.42 & 0.23 & -0.24 & 0.42 & 0.46 \\
\hline \multicolumn{13}{|c|}{ Roots $\geq 1 \mathrm{~cm}$ diameter } \\
\hline Starch & 0.17 & 0.19 & 0.26 & 0.19 & -0.01 & 0.13 & 0.17 & -0.13 & -0.05 & 0.01 & -0.22 & -0.50 \\
\hline Nonreducing sugar & 0.17 & -0.08 & 0.05 & 0.04 & 0.29 & 0.10 & 0.01 & 0.20 & -0.03 & 0.18 & 0.23 & 0.34 \\
\hline Reducing sugar & 0.17 & -0.37 & -0.22 & 0.02 & -0.12 & 0.28 & 0.07 & -0.28 & -0.04 & 0.19 & -0.46 & -0.35 \\
\hline Total & 0.26 & 0.18 & -0.17 & 0.23 & 0.19 & 0.27 & 0.14 & -0.08 & -0.05 & 0.17 & -0.21 & -0.13 \\
\hline
\end{tabular}

****Significantly correlated at $5 \%$ or $1 \%$, respectively. 
Table 3. Coefficients of correlation between nonstructural carbohydrate concentrations in small and large pecan roots during January with the number of flowers produced the following spring from four previous year's shoot types.

\begin{tabular}{|c|c|c|c|c|c|c|c|c|c|c|c|c|}
\hline \multirow{3}{*}{$\begin{array}{l}\text { Nonstructural } \\
\text { carbohydrate }\end{array}$} & \multicolumn{12}{|c|}{ Coefficient of correlation for previous year's shoot type } \\
\hline & \multicolumn{3}{|c|}{ Vegetative shoot } & \multicolumn{3}{|c|}{ Bearing terminal shoot } & \multicolumn{3}{|c|}{ Bearing lateral shoot } & \multicolumn{3}{|c|}{$\begin{array}{l}\text { Bearing with a second } \\
\text { growth flush }\end{array}$} \\
\hline & 2002 & 2003 & 2004 & 2002 & 2003 & 2004 & 2002 & 2003 & 2004 & 2002 & 2003 & 2004 \\
\hline \multicolumn{13}{|c|}{ Roots $<1 \mathrm{~cm}$ diameter } \\
\hline Starch & -0.16 & 0.15 & 0.09 & -0.01 & -0.03 & 0.06 & -0.08 & 0.28 & 0.25 & -0.22 & 0.24 & 0.25 \\
\hline Nonreducing sugar & 0.06 & 0.11 & -0.04 & -0.49 & 0.10 & -0.03 & $-0.59 *$ & -0.02 & -0.18 & -0.21 & -0.14 & 0.16 \\
\hline Reducing sugar & -0.02 & 0.19 & $0.63 *$ & $-0.67 *$ & 0.27 & 0.00 & -0.46 & 0.45 & 0.08 & -0.17 & 0.21 & 0.51 \\
\hline Total & -0.06 & 0.18 & 0.18 & -0.52 & 0.18 & -0.01 & -0.47 & 0.20 & -0.10 & -0.25 & 0.01 & 0.34 \\
\hline \multicolumn{13}{|c|}{ Roots $\geq 1 \mathrm{~cm}$ diameter } \\
\hline Starch & -0.05 & 0.11 & -0.48 & 0.06 & -0.24 & 0.10 & 0.06 & -0.10 & 0.08 & -0.18 & -0.29 & -0.40 \\
\hline Nonreducing sugar & 0.32 & 0.23 & -0.27 & 0.13 & 0.25 & -0.04 & 0.17 & 0.15 & -0.11 & 0.16 & 0.41 & 0.05 \\
\hline Reducing sugar & 0.32 & -0.10 & -0.18 & 0.12 & -0.49 & 0.34 & 0.13 & -0.32 & 0.21 & 0.11 & -0.03 & -0.29 \\
\hline Total & 0.25 & 0.23 & -0.38 & 0.15 & -0.22 & 0.21 & 0.16 & -0.12 & -0.09 & 0.01 & 0.18 & -0.25 \\
\hline
\end{tabular}

*Significantly correlated at $5 \%$.

subsequent flowers/1-year-old branch or percent current season shoots flowering (Tables 2 and 3 ). This suggests that the positive relationship with root starch concentration reported earlier (Malstrom, 1974; Smith and Waugh, 1938; Wood, 1989; Worley 1979a) was possibly a casual relationship rather than causal.

Nonstructural carbohydrate concentration during January in the shoot was rarely correlated with subsequent flowering of current season shoots or the total pistillate flowers produced by the various shoot types (Table 4). In those instances when the correlations were significant, they were negative three of five times. Smith et al. (1986) reported that bearing shoots typically had higher nonstructural carbohydrates than vegetative shoots. This was attributed to the fruit being strong sinks for carbohydrate transport, resulting in higher residual carbohydrates during dormancy. However, return bloom of vegetative shoots was greater than that of bearing shoots, suggesting little relationship between nonstructural carbohydrates stored in the shoots and subsequent flowering. Malstrom (1974) and Wood (1989) reported that nonstructural carbohydrates in shoots were not related to subsequent yield. These reports support the lack of significant correlations between shoot carbohydrates and subsequent flowering reported here, and the occasional negative relationships.

There were no significant correlations of yield with organically bound $\mathrm{N}$ and $\mathrm{K}$ in the roots or shoots the following January (Table 5). Yield during the 3 years averaged 11.1, 21.1 , and $12.6 \mathrm{~kg} /$ tree in 2001, 2002 and 2003 respectively. Individual trees varied from a low of $5.1 \mathrm{~kg} /$ tree to a high of $32.7 \mathrm{~kg} /$ tree. In pistachio (Pistacia vera L.), an alternatebearing fruit, $\mathrm{N}$ was depleted by large crops, suggesting that available $\mathrm{N}$ following a large crop might limit next year's flowering (Rosecrance et al., 1996, 1998). The same scenario has been proposed for alternate-bearing pecans with later summer or fall-applied $\mathrm{N}$ suggested to alleviate this problem (Goff et al., 2001; Kraimer et al., 2004; Wood, 2001b). This

Table 4. Coefficients of correlation between the nonstructural carbohydrate concentration in three pecan shoots types during January with the percentage of current shoots flowering the following spring and the number of pistillate flowers from each shoot type.

\begin{tabular}{|c|c|c|c|c|c|c|}
\hline \multirow{3}{*}{$\begin{array}{l}\text { Nonstructural } \\
\text { carbohydrate }\end{array}$} & \multicolumn{6}{|c|}{ Coefficient of correlation } \\
\hline & \multicolumn{3}{|c|}{ Percentage of current season shoots flowering } & \multicolumn{3}{|c|}{ Number of flowers/branch } \\
\hline & 2002 & 2003 & 2004 & 2002 & 2003 & 2004 \\
\hline \multicolumn{7}{|c|}{ Vegetative shoot } \\
\hline Nonreducing sugar & 0.40 & -0.08 & 0.17 & 0.35 & -0.06 & -0.36 \\
\hline Reducing sugar & $0.60 *$ & -0.20 & 0.08 & 0.35 & -0.18 & -0.21 \\
\hline \multicolumn{7}{|c|}{ Bearing terminal shoot } \\
\hline Starch & -0.46 & $-0.64 *$ & -0.12 & -0.53 & -0.47 & -0.28 \\
\hline Nonreducing sugar & -0.20 & 0.07 & 0.07 & -0.17 & -0.10 & -0.22 \\
\hline Reducing sugar & 0.28 & -0.04 & -0.01 & 0.19 & 0.29 & -0.00 \\
\hline Total & -0.01 & -0.17 & 0.06 & -0.05 & -0.16 & -0.23 \\
\hline \multicolumn{7}{|c|}{ Bearing lateral shoot } \\
\hline Starch & - & - & 0.49 & - & - & 0.01 \\
\hline
\end{tabular}

*Significantly correlated at $5 \%$. 
Table 5. Coefficients of correlation between individual pecan tree yield with organically bound nitrogen $(\mathrm{N})$ and potassium $(\mathrm{K})$ concentration the following January in small and large roots, and three shoot types.

\begin{tabular}{llccr}
\hline \multirow{2}{*}{ Nutrient } & \multicolumn{1}{c}{ Tissue } & \multicolumn{3}{c}{ Coefficient of correlation } \\
\cline { 3 - 5 } $\mathrm{N}$ & Roots $<1 \mathrm{~cm}$ diameter & $0.11^{\mathrm{z}}$ & 0.26 & -0.17 \\
& Roots $\geq 1 \mathrm{~cm}$ diameter & -0.23 & 0.01 & 0.36 \\
& Vegetative shoot & -0.25 & -0.27 & -0.14 \\
& Bearing terminal shoot & 0.23 & -0.21 & -0.16 \\
& Bearing lateral shoot & - & - & -0.08 \\
$\mathrm{~K}$ & Roots $<1$ cm diameter & -0.25 & 0.53 & 0.39 \\
& Roots $\geq 1$ cm diameter & 0.28 & 0.17 & -0.26 \\
& Vegetative shoot & 0.37 & -0.12 & -0.02 \\
& Bearing terminal shoot & 0.53 & -0.28 & 0.45 \\
& Bearing lateral shoot & - & - & -0.08 \\
\hline
\end{tabular}

${ }^{\mathrm{z} N o}$ correlations were significant at the $5 \%$ level.

study suggests that $\mathrm{N}$ was not depleted by large crops. These trees were abundantly supplied with $\mathrm{N}$ from the irrigation water, which may have allowed replenishment of $\mathrm{N}$ during fruit development, following fruit maturation or during dormancy. Also, as reported previously (Acuña-Maldonado et al., 2003; Kraimer et al., 2004; Smith et al., 2004) little $\mathrm{N}$ is typically removed in the crop.

Few significant correlations were detected between January root $\mathrm{N}$ or $\mathrm{K}$ concentration with the percentage of current season shoots flowering (Table 6) or flowers produced from a 1-year-old branch (Table 7) the next growing season. In addition, few significant correlations were found between $\mathrm{N}$ and $\mathrm{K}$ concentrations in the 1-year-old branches and flowering current season shoots or flowers/1-year-old branch (Table 8). This suggests that available $\mathrm{N}$ was not limiting return bloom. One study reported little $\mathrm{N}$ absorbed during the growing season after the initial growth flush. The greatest $\mathrm{N}$ absorption was during rapid shoot growth in the spring, followed by $\mathrm{N}$ absorbed during dormancy (Acuña-Maldonado et al., 2003). Similarly, Smith and Waugh (1938) reported pecan trees absorbed $\mathrm{N}$ during the dormant season. Another study reported rapid $\mathrm{N}$ absorption during kernel filling when $\mathrm{N}$ was applied during September (Kraimer et al., 2004). However, no benefits were detected from spring plus October-applied $\mathrm{N}$ compared with spring-only $\mathrm{N}$ application (Acuña-Maldonado et al., 2003; Smith et al., 2004). The lack of correlation between organically bound $\mathrm{N}$ in January. with previous season's yield suggests that $\mathrm{N}$ was not depleted by large crops. The lack of relationship between organically bound $\mathrm{N}$ in January with the subsequent return bloom indicates that $\mathrm{N}$ was not limiting in this study.

\section{Conclusion}

Evidence presented here suggests that nonstructural carbohydrates should not be viewed as a primary controlling mechanism for flowering or alternate bearing. It is obvious that under certain circumstances that carbohydrates are limiting, because

Table 6. Coefficients of correlation between organically bound nitrogen $(\mathrm{N})$ and potassium $(\mathrm{K})$ concentrations in small and large pecan roots during January with the percentage of current shoots flowering the following spring that developed from four previous year's shoot types.

\begin{tabular}{|c|c|c|c|c|c|c|c|c|c|c|c|c|}
\hline \multirow[b]{3}{*}{ Nutrient } & \multicolumn{12}{|c|}{ Coefficient of correlation for previous year's shoot type } \\
\hline & \multicolumn{3}{|c|}{ Vegetative shoot } & \multicolumn{3}{|c|}{ Bearing terminal shoot } & \multicolumn{3}{|c|}{ Bearing lateral shoot } & \multicolumn{3}{|c|}{$\begin{array}{l}\text { Bearing with a second } \\
\text { growth flush }\end{array}$} \\
\hline & 2002 & 2003 & 2004 & 2002 & 2003 & 2004 & 2002 & 2003 & $\overline{2004}$ & 2002 & 2003 & 2004 \\
\hline $\mathrm{N}$ & -0.12 & -0.29 & -0.46 & 0.17 & 0.13 & -0.47 & 0.08 & -0.24 & -0.48 & -0.26 & 0.38 & -0.39 \\
\hline $\mathrm{K}$ & 0.01 & $-0.64 *$ & $-0.57^{*}$ & 0.28 & $-0.70 * *$ & 0.38 & 0.31 & $-0.75^{* *}$ & -0.54 & 0.22 & $-0.78 * *$ & $-0.74 * *$ \\
\hline \multicolumn{13}{|c|}{ Roots $\geq 1 \mathrm{~cm}$ diameter } \\
\hline K & 0.13 & -0.21 & $0.64^{*}$ & 0.06 & -0.27 & 0.11 & 0.03 & -0.46 & 0.49 & 0.09 & -0.27 & 0.44 \\
\hline
\end{tabular}

,*** Significantly correlated at $5 \%$ or $1 \%$, respectively.

Table 7. Coefficients of correlation between organically bound nitrogen $(\mathrm{N})$ and potassium $(\mathrm{K})$ concentrations in small and large pecan roots during January with the number of pistillate flowers/branch that developed the following spring from four previous year's shoot types.

\begin{tabular}{|c|c|c|c|c|c|c|c|c|c|c|c|c|}
\hline \multirow[b]{3}{*}{ Nutrient } & \multicolumn{12}{|c|}{ Coefficient of correlation for previous year's shoot type } \\
\hline & \multicolumn{3}{|c|}{ Vegetative shoot } & \multicolumn{3}{|c|}{ Bearing terminal shoot } & \multicolumn{3}{|c|}{ Bearing lateral shoot } & \multicolumn{3}{|c|}{$\begin{array}{l}\text { Bearing with a second } \\
\text { growth flush }\end{array}$} \\
\hline & 2002 & 2003 & 2004 & 2002 & 2003 & 2004 & 2002 & 2003 & 2004 & 2002 & 2003 & 2004 \\
\hline $\mathrm{N}$ & -0.53 & -0.26 & -0.34 & 0.06 & -0.36 & -0.28 & -0.03 & -0.33 & $-0.68^{*}$ & -0.39 & -0.32 & -0.56 \\
\hline K & -0.01 & -0.56 & -0.31 & 0.21 & $-070 *$ & -0.07 & 0.15 & $-0.84 * * *$ & -0.14 & 0.28 & -0.53 & -0.49 \\
\hline K & 0.13 & -0.27 & 0.44 & 0.11 & -0.24 & -0.01 & 0.10 & -0.35 & 0.37 & -0.08 & -0.09 & $0.61^{*}$ \\
\hline
\end{tabular}


Table 8. Coefficients of correlation between organically bound nitrogen $(\mathrm{N})$ and potassium $(\mathrm{K})$ concentration in 1-year-old pecan branches during January with the percentage of current shoots flowering the following spring and the number of flowers per 1-year-old branch.

\begin{tabular}{|c|c|c|c|c|c|c|}
\hline \multirow[b]{3}{*}{ Nutrient } & \multicolumn{6}{|c|}{ Coefficient of correlation } \\
\hline & \multicolumn{3}{|c|}{$\begin{array}{c}\text { Percentage of current } \\
\text { season shoots flowering }\end{array}$} & \multicolumn{3}{|c|}{$\begin{array}{c}\text { Number of } \\
\text { flowers/branch }\end{array}$} \\
\hline & 2002 & 2003 & 2004 & 2002 & 2003 & 2004 \\
\hline \multicolumn{7}{|c|}{ Vegetative shoot } \\
\hline $\mathrm{N}$ & $-0.20^{\mathrm{z}}$ & -0.22 & 0.29 & 0.11 & -0.31 & -0.14 \\
\hline K & 0.12 & -0.29 & 0.20 & 0.16 & -0.12 & 0.05 \\
\hline \multicolumn{7}{|c|}{ Bearing terminal shoot } \\
\hline $\mathrm{N}$ & 0.06 & 0.13 & 0.14 & -0.15 & 0.15 & 0.04 \\
\hline K & 0.51 & -0.17 & -0.41 & -0.27 & -0.21 & -0.22 \\
\hline \multicolumn{7}{|c|}{ Bearing lateral shoot } \\
\hline $\mathrm{N}$ & - & - & 0.22 & - & - & -0.12 \\
\hline K & - & - & 0.01 & - & - & 0.43 \\
\hline
\end{tabular}

${ }^{\mathrm{Z}}$ No correlations were significant at the $5 \%$ level.

they can be depleted to the point that tree survival is questionable (Wood, 2001a). However, in such circumstances it is unlikely that flower induction occurred and is therefore immaterial if carbohydrates were low. Wood et al. (2003) recently dispelled some commonly held views concerning alternate bearing. They found no relationship between fruit ripening date and alternate bearing. It had been assumed that early fruit ripening would reduce alternate bearing because there would be a longer postripening period before defoliation, giving trees time to replenish depleted carbohydrates. In fact, they found a shorter postripening foliation period reduced alternate-bearing intensity. It was also assumed that small fruit would create less carbohydrate demand and therefore reduce alternate-bearing intensity. Results of their study indicated no relationship between fruit volume and alternate-bearing intensity. Similarly, Rohla et al. (2005) found weak or nonsignificant relationships between fruit/cluster and return bloom. Their results combined with these further support the contention that flowering, and consequently alternate-bearing intensity, is primarily controlled by factors other than nonstructural carbohydrate concentrations in the roots or shoots during the dormant season.

Potassium is an integral part of several plant processes and is involved in phloem transport. A deficiency of $\mathrm{K}$ would make the value of these results questionable. Results indicate that $\mathrm{K}$ was not limiting. Potassium reserves in the roots or shoots were not related to the previous crop load or subsequent flowering.

Depletion of $\mathrm{N}$ reserves by large crops has been proposed to contribute to alternate bearing (Goff et al., 2001; Kraimer et al., 2004; Wood, 2001b). Results indicated that $\mathrm{N}$ in the roots and shoots during Jan. was not related to the previous crop load or subsequent flowering. Trees were supplied with abundant $\mathrm{N}$ from contaminated irrigation water; therefore, we were unable to determine reliably the extent that $\mathrm{N}$ was depleted by the developing crop, because additional $\mathrm{N}$ could be absorbed to meet demand. Our results do indicate that $\mathrm{N}$ reserves were not correlated with subsequent flowering. Nitrogen is obviously essential to maintain growth and orchard productivity; however, these results clearly indicate that abundant $\mathrm{N}$ does not ensure subsequent flowering and reduced alternate bearing.

\section{Literature Cited}

Acuña-Maldonado, L.E., M.W. Smith, N.O. Maness, B.S. Cheary, and B.L. Carroll. 2003. Influence of nitrogen application time on nitrogen absorption, partitioning, and yield of pecan. J. Amer. Soc. Hort. Sci. 128:155-162.

Amling, H.J. and K.A. Amling. 1983. Physiological differentiation of pistillate flowers of pecan and cold requirements for their initiation. J. Amer. Soc. Hort. Sci. 108:195-198.

Barnett, J. and E.A. Mielke. 1981. Alternate bearing: A re-evaluation. Pecan South 8:20-23.

Brooks, O.L. and R. Livingston. 1962. A progress report on results of fertility studies with pecan. Proc. Southeastern Pecan Growers' Assn. 55:44-47.

Diver, S.G. and M.S. Smith. 1984. Influence of fruit development on seasonal elemental concentrations and distribution in fruit and leaves of pecan. Commun. Soil Sci. Plant Anal. 15:619-637.

Gemoets, E.E., L.A. Gemoets, T.E. Cannon, and R.G. McIntyre. 1976. Cycles in U.S. pecan production 1919-1974 identified by power spectral analysis. J. Amer. Soc. Hort. Sci. 101:550-553.

Goff, B., M. Nesbitt, and C. Browne. 2001. Late season fertilization: An exciting new development for the pecan industry. Proc. Southeastern Pecan Growers' Assn. 94:91-93.

Haeder, H.E. 1977. Effects of potassium on phloem loading and transport: Fertilizer use and production of carbohydrates and lipids. Proc. Colloq. Intl. Potash Inst. 13:115-121.

Hodge, J.E. and B.T. Hofreiter. 1962. Determination of reducing sugars and carbohydrates, p. 300-394. In: R.L. Whistler and J.L. Wolfrom (eds.). Methods in carbohydrate chemistry, Vol. 1. Academic Press, New York.

Horowitz, W. 1980. Official methods of analysis of the association of analytical chemists. 13th ed. Assn. Offic. Anal. Chemists, Washington, D.C.

Hunter, J.H. 1964. Time of applying nitrogen to pecan trees in sod. Proc. Southeastern Pecan Growers' Assn. 57:18-22.

Hunter, J.H. and H.E. Hammar. 1947. The results of applying different fertilizers to the Moore variety of pecan over a ten-year period. Proc. Southeastern Pecan Growers' Assn. 40:10-32.

Hunter, J.H. and H.E. Hammar. 1956. Relation of oil content of pecan kernels to chemical components of leaves as a measurement of nutrient status. Soil Sci. 82:261-269.

Hunter, J.H. and H.E. Hammar. 1961. Effects of different grades and rates of fertilizers applied to Schley pecan trees as influenced by other factors. Proc. Southeastern Pecan Growers' Assn. 54:29-41.

Kraimer, R.A., W.C. Lindemann, and E.A. Herrera. 2004. Recovery of late-season $15 \mathrm{~N}$-labeled fertilizer applied to pecan. HortScience 39:256-260.

Krezdorn, A.H. 1955. The nutrient status of pecan leaves in relation to alternate bearing. Proc. Texas Pecan Growers' Assn. 34: $43-53$.

Lalonde, S., M. Tegeder, M. Throne-Holst, W.B. Frommer, and J.W. Patrick. 2003. Phloem loading and unloading of sugars and amino acids. Plant Cell Environ. 26:37-56.

Malstrom, H.L. 1974. The relationship of stored reserves to yield in mature pecan trees. Proc. Western Pecan Conf. 8:65-69.

Mengel, K. 1980. Effect of potassium on the assimilate conduction to storage tissue. Ber. Dtsch. Bot. Ges. 93:353-362.

Mengel, K. and H. Haeder. 1977. Effect of potassium supply on the rate of phloem sap exudation and the composition of phloem sap of Ricinus communis. Plant Physiol. 59:282-284.

Rohla, C.T., M.W. Smith, and N.O. Maness. 2005. Effects of cluster size and shoot type on characteristics of pecan nuts. HortScience 40:1300-1303.

Rosecrance, R.C., S.A. Weinbaum, and P.H. Brown. 1996. Assessment of nitrogen, phosphorus, and potassium uptake capacity and root growth in mature alternate-bearing pistachio (Pistacia vera) trees. Tree Physiol. 16:949-956. 
Rosecrance, R.C., S.A. Weinbaum, and P.H. Brown. 1998. Alternate bearing affects nitrogen, phosphorus, potassium and starch storage pools in mature pistachio trees. Ann. Bot. (Lond.) 82:463470.

Skinner, J.J. 1922. Influence of fertilizers on the yield, size and quality of pecans. Proc. Georgia-Florida Pecan Growers' Assn. 16:50-56.

Smith, M.W., P.L. Ager, and D.S.W. Endicott. 1985. Effect of nitrogen and potassium on yield, growth, and leaf elemental concentration of pecan. J. Amer. Soc. Hort. Sci. 110:446-450.

Smith, M.W., B.L. Carroll, and B.S. Cheary. 2004. Response to pecan to nitrogen rate and nitrogen application time. HortScience 39:14121415.

Smith, C.L. and J. Hamilton. 1937. Effects of nitrogen fertilizer on growth and yield of pecan trees growing in unproductive sandy soil. Proc. Texas Pecan Growers' Assn. 17:25-31.

Smith, M.W., R.W. McNew, P.L. Ager, and B.C. Cotton. 1986. Seasonal changes in the carbohydrate concentration in pecan shoots and their relationship to flowering. J. Amer. Soc. Hort. Sci. 111:558561.

Smith, C.L. and J.G. Waugh. 1938. Seasonal variations in the carbohydrate and nitrogen content of roots of bearing pecan trees. J. Agr. Res. 57:449-460.

Sparks, D. 1968. Some effects of nitrogen on young pecan trees. Proc. Southeastern Pecan Growers' Assn. 61:93-102.

Sparks, D. 1977. Effects of fruiting on scorch, premature defoliation, and nutrient status of 'Chickasaw' pecan leaves. J. Amer. Soc. Hort. Sci. 102:669-673.

Sparks, D. and C.E. Brack. 1972. Return bloom and fruit set of pecan from leaf and fruit removal. HortScience 7:131-132.

Taylor, R.W. 1930. Influence of fertilizer treatments on yield and quality of pecans. Natl. Pecan Assn. Bul. 29:18-22.

von Broembsen, S. and P. Mulder. 2005. Commercial pecan disease and insect control-2006. Oklahoma Coop. Ext. Serv. CR-6209.

Vreugdenhil, D. 1985. Source-to-sink gradient of potassium in the phloem. Planta 163:238-240.
Wood, B.W. 1984. Free and bound abscisic acid and free gibberellinlike substances in pecan kernel tissue during seed development. J. Amer. Soc. Hort. Sci. 109:626-629.

Wood, B.W. 1989. Pecan production responds to root carbohydrates and rootstock. J. Amer. Soc. Hort. Sci. 114:223-228.

Wood, B.W. 1991. Alternate bearing in pecan, p. 180-190. In: B.W. Wood and J.A. Payne (eds.) Pecan husbandry: Challenges and opportunities. Proc. First National Pecan Workshop, U.S. Dept. Agr., Agr. Res. Serv., ARS-96.

Wood, B.W. 1993. Production characteristics of the United States pecan industry. J. Amer. Soc. Hort. Sci. 118:538-545.

Wood, B.W. 2001a. Atypical symptoms of cold damage to pecan. HortScience 36:298-301.

Wood, B.W. 2001b. Managing nitrogen in pecan orchards. Proc. Southeastern Pecan Growers' Assn. 94:153-159.

Wood, B.W. 2003. Pecan production in North America. Southwestern Entomol. Suppl. 27:1-19.

Wood, B.W., P.J. Conner, and R.E. Worley. 2003. Relationship of alternate bearing intensity in pecan to fruit and canopy characteristics. HortScience 38:361-366.

Wood, B.W. and J.L. McMeans. 1981. Carbohydrate changes in various organs of bearing and nonbearing pecan trees. J. Amer. Soc. Hort. Sci. 106:758-761.

Worley, R.E. 1974. Effect of N, P, K, and lime on yield, nut quality, tree growth, and leaf analysis of pecan (Carya illinoensis W). J. Amer. Soc. Hort. Sci. 99:49-57.

Worley, R.E. 1979a. Fall defoliation date and seasonal carbohydrate concentration of pecan wood tissue. J. Amer. Soc. Hort. Sci. 104:195-199.

Worley, R.E. 1979b. Pecan yield, quality, nutlet set, and spring growth as a response of time of fall defoliation. J. Amer. Soc. Hort. Sci. 104:192-194.

Worley, R.E. 1990. Long-term performance of pecan trees when nitrogen application is based on prescribed threshold concentrations in leaf tissue. J. Amer. Soc. Hort. Sci. 115:745-749. 